\title{
Scenografija operete na Slovenskem v luči zgodovinske avantgarde
}

\author{
Ana Kocjančič \\ Samostojna raziskovalka \\ Independent researcher
}

Avantgardno gibanje je slovenska poklicna gledališča zajelo v tridesetih letih dvajsetega stoletja. Tedaj so režiserji in scenografi mlajše generacije, med njimi Ferdo Delak (1905-1968) in Bratko Kreft (1905-1996), na naše poklicne gledališke in operne odre zanesli nove likovne in gledališke smernice. Prve gledališke izkušnje so si nabirali pri priznanih gledaliških imenih v tujini (E. Piscator (1893-1966), H. Walden (1893-1966) in R. Blümmer (1873-1945)). Hkrati so spremljali sočasne gledališke smernice $\mathrm{v}$ tujem strokovnem tisku (predvsem jih je zanimalo gledališče V. E. Meyerholda (1874-1940) in A. Tairova (1885-1950)), se $z$ določenimi predstavniki sodobne avantgardne generacije srečevali in ustvarjali (npr. Delak z E. Piscatorjem, italijanskim futuristom F. T. Marinettijem (1876-1944) in G. Carmelichem (19071929)), obiskovali njihove predstave v tujini ter svoje znanje najprej prenesli na amaterske in ljudske odre na Slovenskem.

Ferdo Delak je v avantgardni reviji Tank ${ }^{\mathrm{I}}$ zbral različne traktate in manifeste avantgardnih teoretikov in pomembnih gledaliških ustvarjalcev ter v njej zapisal tudi svoje poglede na sodobno oblikovanje odrskega prostora ter režijo, ki so seveda nastali pod vplivi novih evropskih gledaliških smernic. Scenografijo je poimenoval dekoracija, ki je le »objektivno predstavljena grafična vsebina igre ${ }^{2}$ in je kot taka skupek barv, luči v prostoru in času,

1 Tank: revue internationale active (Ljubljana: Josip Pavliček, 1927).

2 Ferdo Delak in August Černigoj, »Kaj je umetnost? Moderni oder«, v TANK! Slovenska zgodovinska avantgarda, ur. Breda Ilich Klančnik in Igor Zabel (Ljubljana: Moderna galerija, 1998), 50 . 
ki so združene »z lučjo zvoka (dejanje) v prostoru in času (oder in gib) «. Prav ta »sintetična skupnost « različnih zvrsti je »sama na sebi scenična dekoracija od začetka do konca igre«. ${ }^{4}$ Opredelil pa je tudi delo sodobnega režiserja, ki mora biti hkrati pesnik, slikar, arhitekt in gledalec, zato ima v rokah tudi inscenacijo. ${ }^{5} \mathrm{~V}$ traktatih se je Delak vsaj teoretično odrekel nepotrebni odrski opremi in kulisam, kajti kot bomo videli, se je moral tudi on ob vstopu na poklicne odre prilagoditi in spremeniti svoje cilje.

Podobno je v zapisih o sodobni scenografiji in režiji pisal Bratko Kreft, ki je smatral inscenacijo za "zelo mlado umetnost «. ${ }^{6}$ Poudaril je, da v modernem gledališču scena pomaga igralcu in režiserju osmisliti prostor. $\mathrm{V}$ enem izmed zapisov pa je opisal tudi preprost, a koristen scenski element, to je praktikabel. Ta omogoča postavitev scenskih elementov $\mathrm{v}$ vse smeri in višine odrskega prostora, torej omogoča dinamiko in trodimenzionalne, fantazijske rešitve v scenografiji. ${ }^{7}$ Prav praktikable je Kreft kot scensko osnovo uporabljal pri številnih uprizoritvah in z njimi sestavljal dinamične, razgibane scenografije. Za razliko od Delaka je menil, da je inscenacija še vedno v podrejenem položaju režiji in igri, ter je le ilustracija, dopolnitev in podpora besedilu. ${ }^{8}$

Oba režiserja pa sta se ob vstopu na poklicne odre morala prilagoditi tamkajšnjim razmeram. Vsega, kar sta prikazala na Delavskem odru v Ljubljani, ki sta ga nekaj časa tudi vodila, in na ostalih amaterskih odrih, namreč v poklicnih gledališčih nista mogla izpeljati $z$ istimi izraznimi sredstvi, tega ni želelo niti občinstvo, niti vodstvo in pri tem so ju omejevale slabe finančne in tehnične razmere. Zdi se, da so avantgardna hotenja njune generacije na naše poklicne odre vstopila fragmentarno, le kot okrnjeno izpeljane ideje $\mathrm{z}$ različnimi skromnimi in dovoljenimi, avantgardnimi režijskimi vložki in postavljenimi scenskimi elementi ter vpeljano svetlobno in filmsko projekcijo.

3 Ibid.

4 Ibid.

5 Ibid.

6 K. B. [Bratko Kreft], »Nekaj o inscenacijskih problemih (Odlomek iz študije 'Problemi sodobnega gledališča')«, Gledališki list ljubljanske Drame 18, št. 7 (1938/39): 53, http://www.dlib.si/?URN=URN:NBN:SI:DOC-CCGKOBED.

$7 \quad$ Ljubljanski dramska in operna hiša v tem času nista imeli vrtljivih odrov. Opera ga je dobila šele v sezoni 1934/35. Kreft je kot dober poznavalec tehničnih zmogljivosti naših odrov hitro sprevidel, da je mogoče dinamizirati odrski prostor le z obstoječimi pogrezali ter nastavljivimi praktikabli.

$8 \quad$ Kreft, »Nekaj o inscenacijskih problemih«, 56. 


\section{Razvoj operetne scenografije na ljubljanskem odru pred sezono 1929/309}

Med ljudstvom priljubljena opereta je ves čas v obdobju med obema vojnama predvsem polnila vedno prazno gledališko blagajno. ${ }^{10}$ Njeno priljubljenost med publiko je poleg lahkotnosti glasbe krepila tudi barvita in razkošna dekorativna podoba scenskega ozadja, ki je dolgo časa, včasih tudi v pozno obdobje druge polovice tridesetih let, vztrajala na kulisni, škatlasti osnovi. Če je v slovenskem gledališču in operi v drugi polovici tridesetih let, predvsem pod scenografskimi prijemi slikarja Ivana Vavpotiča (1877-1943) in arhitekta Rada Kregarja (1893-1962), naturalistično, kulisno-škatlasto scensko podobo zamenjal sodobnejši ekspresionistični tip tako imenovane razkosane kulisne scene, ki naj bi tudi akustično ustrezal ekspresionističnim besedilom in izvedbam, so bile operete tega časa še vedno zasnovane s podobami preteklosti. Dovolj dobra so bila že barvito prenovljena, predelana in dekorirana prizorišča iz starega gledališkega fundusa. Zdi se, da ravno zaradi te težnje po recikliranju starega materiala za scensko ozadje, operetna scenografija vse do tridesetih let ni dosegla tistega stilnega razvoja, ki sta ga naša operna in gledališka scenografija.

Med najzgodnejše ohranjene zapise o uprizoritvah operet po prvi svetovni vojni sodi pričevanje o postavitvi Hervéjeve Mamzelle Nitouche na ljubljanskem odru (27. 1. 1919, režija: V. Marek). V dnevnem časopisu se je predstava ohranila kot anekdota ${ }^{\text {II }} \mathrm{s}$ scenskim podatkom o uporabi kulis in s pričevanjem o prisotnosti pravih konj na odru. Živali so bile tudi v prvih

9 Velika ovira pri raziskovanju scenografije časa med obema vojnama je vedno močno pomanjkanje slikovnega gradiva. To velja tudi za raziskovanje scenografije operet. Pri tem je v prednosti ljubljanski oder, saj je tu ohranjenega gradiva več. Pri mariborskem odru pa si moramo raziskovalci večkrat pomagati le $\mathrm{z}$ domišljijo, naslonjeno na redke opise scenskih detajlov v kritikah. Opisi operetne scenografije tega časa so relativno skopi in jih najdemo v kritikah le tedaj, ko gre za izjemno postavitev, ali pa je likovna podoba tako slaba, da ji je potrebno nameniti kako vrstico več. Malce bolje so dokumentirane predstave po letu 1930.

1o Zanimivo je, da je bil obisk operetnih predstav zelo dober kljub dejstvu, da so si obiskovalci lahko sočasno ogledovali operete (včasih celo z istimi naslovi) v kinu ali pa jih poslušali prek radia.

11 V opereti je vlogo majorja pel igralec Anton Cerar - Danilo. Ob njem so bili v istem prizoru na odru tudi pravi konji. $V$ trenutku razigranosti je eden izmed konj brcnil v kuliso, ki se je prevrnila na znamenitega slovenskega igralca. Glej: n., »Narodno gledališče. 'Mam'zelle Nitouche'«, Slovenski narod 52, št. 23 (28. januar 1919): 3, http:// www.dlib.si/?URN=URN:NBN:SI:doc-R2BQ 3 BGH. Pa tudi: Ana Kocjančič, Prostor $v$ prostoru, Scenografija na Slovenskem od 17. stoletja do leta 1991, vol. I. (Ljubljana: Slovenski gledališki inštitut, 2018), 66-7. 
letih povojnega gledališča še vključene $\mathrm{v}$ predstave. $\mathrm{Z}$ njimi so popestrili dogajanje in okrepili realistični videz uprizoritvam. Isto opereto so dve leti kasneje igrali tudi na mariborskem odru. Od mariborske izvedbe (1. 5. 1920, režija: R. Železnik) pa se je ohranila fotografija, na kateri je delno razvidno prizorišče, narejeno s kulisami in prospektom $\mathrm{z}$ naslikano orgelsko omaro. Ob primerjavi lahko izluščimo, da sta bili obe opereti, kot je bila v tistih časih splošna navada, postavljeni še $\mathrm{v}$ škatlastem prostoru, $\mathrm{s}$ kulisami in prospekti, $\mathrm{v}$ tako imenovanem naturalističnem stilu.

Po ostalem delno ohranjenem slikovnem in pisnem gradivu tega obdobja, so kulisna, škatlasta prizorišča kasneje malce razgibali in popestrili predvsem s postavitvijo $\mathrm{v}$ več segmentov razdeljenih prizorišč hkrati na isti oder. Piskačkova Slovaška princeska (15. 3. 1919, režija V. Marek, scenografija V. Marek in V. Skrušny, Opera Narodnega gledališča v Ljubljani) je na primer imela dvodelno prizorišče, Straussov Cigan Baron (26. 4. 1929, režija J. Povhe, Opera Narodnega gledališča v Ljubljani) pa skoraj simetrično, na tri dele razdeljeno, prizorišče. Iz istega obdobja sta se ohranila tudi dva zanimiva scenska osnutka scenografa Ivana Vavpotiča za Hirskega opereto Zmagovalka oceana (21. 1. 1928, režija J. Povhe, Opera Narodnega gledališča $v$ Ljubljani). Najstarejši znani skici operetnih prizorišč, hranjeni v zbirki SLOGI - Gledališkega muzeja, s svojo napredno in sodobno stilno usmerjenostjo v art deco kažeta na to, da je pisanje o razvoju operetne scenografije pred letom 1929 prav zaradi skope ohranjenosti slikovnega in pisnega gradiva lahko le fragmentarno, osredotočeno na posamične postavitve in zato ne kaže nepretrganega razvoja.

\section{Operni ravnatelj Mirko Polič in razvoj operetne scenografije} v sezoni 1929/30

Prav v tridesetih letih 20. stoletja, v času, ki ga zaradi razvoja in približanja gledaliških smeri sodobnim evropskim tokovom označujemo s terminom evropeizacija slovenskega gledališča, ${ }^{12}$ je v operni hiši prišlo do pomembnih novih sprememb in dogajanj, ki so pohitrila razvoj režije in scenografije na njenem odru. Leta 1925 je postal ravnatelj Opere dirigent Mirko Polič (1890-1951), ki je okrog sebe zbral sposobne mlade ustvarjalce, s katerimi je poskušal izoblikovati novo podobo slovenske opere in operete. Leta 1928 so v Operi razpisali edinstven scenografski natečaj za Kogojevo ope-

12 Filip Kalan, »Evropeizacija slovenske gledališke kulture«, v Linhartovo izročilo, ur. Lojze Filipič (Ljubljana: Drama Slovenskega narodnega gledališča, 1957), 30-168. 
ro Črne maske, ${ }^{13}$ na katerega je ravnatelj Polič povabil svoje mladostne tržaške in primorske kolege, predstavnike slovenskega avantgardnega gibanja: Avgusta Černigoja (1898-1985), Ivana Čarga (1898-1958), Iva Spinčiča (19031985), ${ }^{14}$ Edvarda Stepančiča (1908-1991) in Ferda Delaka. Poleg njih pa se je na natečaj prijavil še hišni scenograf Ivan Vavpotič. Prispeli scenski osnutki so bili narejeni po sodobnih likovnih, arhitekturnih in scenografskih smernicah, od Vavpotičeve ekspresionistične zasnove do najbolj avantgardne zamisli Edvarda Stepančiča, ki se je poigral z različnimi odrskimi višinami ter igro svetlobe. ${ }^{15}$ Zmagala pa je konservativna, ekspresionistična, kulisna scenska ideja hišnega scenografa Vavpotiča, tudi zato, ker se je tedaj ekspresionizem kot stil že dobro ukoreninil v slovensko likovno umetnost in kot tak postal sprejemljiv v umetniških in gledaliških krogih.

Po neuspelem poskusu, da bi Kogojevo opero videli v sodobnejši, avantgardni opravi, je Mirko Polič še naprej vztrajal pri modernizaciji režije in scenografije. Pri tem mu je pomagal novi hišni scenograf, rusko šolan Ukrajinec Vasilij Uljaniščev (1887-1934). ${ }^{16} \mathrm{Na}$ oba ljubljanska odra (dramskega in opernega) je ob svojem prihodu maja leta 1930 prinesel sodobnejše scenografske prakse, temelječe na avantgardnih novostih. Med njimi je izstopala postavitev Delannoyevega baleta Damski lovec (15. 10. 1931, Opera Narodnega gledališča v Ljubljani), ki ga je, tako v kostumskem kot scenografskem smislu, osnoval $\mathrm{z}$ očitnim naslonom na gledališko delavnico nemške, umetniške šole Bauhaus, predvsem na znameniti Triadični balet Oskarja Schlemmerja (1888-1943). ${ }^{17}$

Hkrati ni zanemarljivo dejstvo, da se je v tem obdobju na ljubljanskem opernem odru zvrstilo kar nekaj avantgardno zasnovanih uprizoritev, ki niso bile del rednega opernega repertoarja, temveč so prišle $\mathrm{v}$ operno hišo kot gostujoče predstave amaterskih odrov, med njimi tudi predstave Delavskega odra v Ljubljani. Operni oder je bil odlična referenca, bil je večji in tehnično zmogljivejši, kar je ustvarjalcem amaterskih odrov omogočalo več svobode pri ustvarjanju. Z Delavskim odrom je tu gostoval tudi

13 Kogojevo opero Črne maske so v scenografiji Ivana Vavpotiča premierno uprizorili 7. maja 1929 v režiji Borisa Kriveckega.

14 Ivo Spinčič je kot scenograf leto prej sodeloval na odru Narodnega gledališča v Ljubljani, kjer je postavil sodoben interier pri Kulundžičevi Polnoči (19. 10. 1927, režija Ciril Debevec). Ostali se z delom na poklicnih gledaliških odrih še niso srečali.

15 Ferdo Delak, „Scenični osnutki Kogojeve opere Črne maske«, Ilustracija 1, št. 6 (1929): 182 .

16 Pred prihodom v Ljubljano je Uljaniščev nekaj časa deloval tudi kot scenograf moskovskega Hudožestvenega gledališča in si tam pridobil pomembne izkušnje. 
režiser Ferdo Delak. Med drugim je v novi inscenaciji Ljuba Ravnikarja (1905-1973) in z govornim zborom premierno uprizoril Cankarjevega Hlapca Jerneja (21. 5. 1932). ${ }^{18}$ Uprizoritev je bila režijsko, dramaturško in scenografsko izredno pomembna, saj je temeljila na skoraj performativno predelanem Cankarjevem besedilu, ki je bilo na odru prezentirano s projekcijo $\mathrm{v}$ parole prirejenih, skrajšanih citatov in politično provokativnih scenskih podob. Z uspešno in priljubljeno predstavo sta Delak in Ravnikar še leta gostovala po slovenskih amaterskih odrih. Kot se je izkazalo ob zadnjih raziskavah, pa sta $\mathrm{z}$ njo, $\mathrm{v}$ novi igralski zasedbi, po drugi svetovni vojni otvorila tudi Slovensko gledališče v Trstu. ${ }^{19}$

Sočasno se je na ljubljanskem opernem odru občinstvu predstavil tudi študent arhitekture Bojan Stupica (1910-1970) s svojo gledališko skupino Obrazniki. Uprizorili so vojno dramo Paula Raynala Le tombeau sous l'arc de triomphe, preimenovano v Vojna in mir (21. 12. 1931). ${ }^{20}$ Predstava je zaradi številnih težav na odru povsem propadla, a je v scenografiji že kazala Stupičeve težnje po sodobni, v realizem usmerjeni scenski podobi, kakršne pri nas še nismo videli. Kmalu nato je Stupica dobil povabilo za sodelovanje na mariborskem odru, kjer je zablestel kot režiser in scenograf dramskih predstav in se lotil postavitve Stolzovega Izgubljenega valčka (25. 12. 1934).

Vsi ti dogodki v Operi so v hišo prinašali nove smernice, pa tudi željo po novem, drugačnem, hkrati pa nevsiljivo seznanjali sicer konservativno publiko z novimi gledališkimi praksami. Te so iz amaterskega miljeja počasi prodirale na naše poklicne odre.

\section{Operetna scenografija ob režijah Bratka Krefta}

Ravnatelj Mirko Polič je torej želel modernizirati operne, pa tudi operetne predstave. Pionirsko je poskusil z uvedbo profesionalnih režiserjev, ki jih do tedaj ljubljanska operna hiša ni imela. To delo so namreč opravljali operni kapelniki. V nekem intervjuju je ponosno povedal, da bodo v novem letu mesto opernega režiserja zasedli dramski režiserji Osip Šest (18931962), Ciril Debevec (1903-1973), Bratko Kreft in Ferdo Delak. Prav posebno

18 I. V., »Delavski oder 'Svobode' v Ljubljani. Uprizoritev Cankarjevega 'Hlapca Jerneja in njegove pravice' v operi. - Nova inscenacija. - Govorilni zbor«, Delavska politi$k a$ 7, št. 41 (21. maj 1932): 3.

19 Ana Kocjančič, Prostor v prostoru, Scenografija na Slovenskem od 17. stoletja do leta 1991, vol. II. (Ljubljana: Slovenski gledališki inštitut, 2018), 48.

20 Anon., »Stremljenje obraznikov v gledališču (razgovor urednika z Milanom Skrbinškom)«, Jutro: ponedeljska izdaja 12, št. 294a (21. december 1931): 2, http://www.dlib. si/?URN=URN:NBN:SI:DOC-HXOQISCF. 
je poudaril sodelovanje s Kreftom in Delakom, z dvema "novo stvariteljema«, kot ju je poimenoval, ki naj bi bila še posebej uporabna pri moderni literaturi in pa tam, kjer je treba najti starejšim delom sodobnejši izraz. ${ }^{21}$ Kot sodelavca pa jim je ponudil scenografa Vasilija Uljaniščeva. Tako je operni oder postal preskusna deska za režijske in scenografske novotarije, ki bi težko prišle in uspele na ostalih poklicnih odrih pri nas.

V operno hišo je Polič povabil mladega režiserja Bratka Krefta, ki je ravno takrat iskal redno zaposlitev, a na ljubljanskem dramskem odru, kamor je želel, prav zaradi svojih teženj po novostih in zaradi avantgardnih zamisli, tedaj še ni bil zaželen. Na opernem odru pa je po prvem uspešnem debutu s postavitvijo Audranove La Mascotte (9. 11. 1930, scenografija: V. Uljaniščev) ustvarjal do leta 1932.

Kreft je želel graditi sodobno režijo, igro in scenografijo pod vplivom avantgardnih nemških in ruskih odrov. V intervjujih je nazorno nakazal naslon na Tairova in Reinharda, ki sta se prav tako odločala za režije sodobnih operet, ki naj bi postale prave »umetniške uprizoritve «, ne pa plitve, komercialne uprizoritve tipa dunajska opereta. ${ }^{22} \mathrm{~V}$ novi opereti je videl celostno umetnino, v kateri se stekajo vsi tokovi gledališke umetnosti: igralstvo, petje in balet ter po zgledu Tairova tudi umetnost akrobatov. Vzpostavil je »kolektivno režijo«, sodobni balet in akrobacije ter kot glavni scenski element za dinamiziranje scene uporabljal praktikable, različne višine, napisane parole in projekcije. ${ }^{23}$

Pri La Mascotte je posodobil libreto ter ga kot satiro spremenil v sodobno »commedio dell'arte«. Celotno predstavo je gradil po zgoraj zapisanih Tairovih načelih. Baletni zbor je sprva nastopil v vlogi lovcev, nato pa $\mathrm{v}$ vlogi vojakov s protiplinskimi maskami. Eden izmed pevcev je celo nosil masko, ki je malce spominjala na Mussolinija. Na odru je v drugem dejanju stala visoka lestev, po kateri so balerine izvajale cirkuške akrobacije. Nastopil je baletnik v podobi Charlieja Chaplina in mednarodni športni sodnik kot delegat Društva narodov s parolo v rokah. Zbor je prihajal na oder $\mathrm{z}$ vseh strani, balet pa je nastopal po sistemu »girls«, kar je bila na naših odrih popolna novost.

Sodobni in razgibani režiji je sledila tudi scenografija. Zasnoval jo je Vasilij Uljaniščev. Bila je preprosta, simetrična, a zračna, brez škatlaste ob-

21 Dušan Moravec, Slovenski režiserski kvartet (z gostom) (Ljubljana: Slovenski gledališki in filmski muzej, 1996), 192.

22 Ibid.

23 Med scenografsko slabše zasnovane Kreftove predstave je sodila le Novakova Laterna (8. 10. 1931), ki je bila postavljena $\mathrm{v}$ škatlast prostor s preprostimi kulisami. 


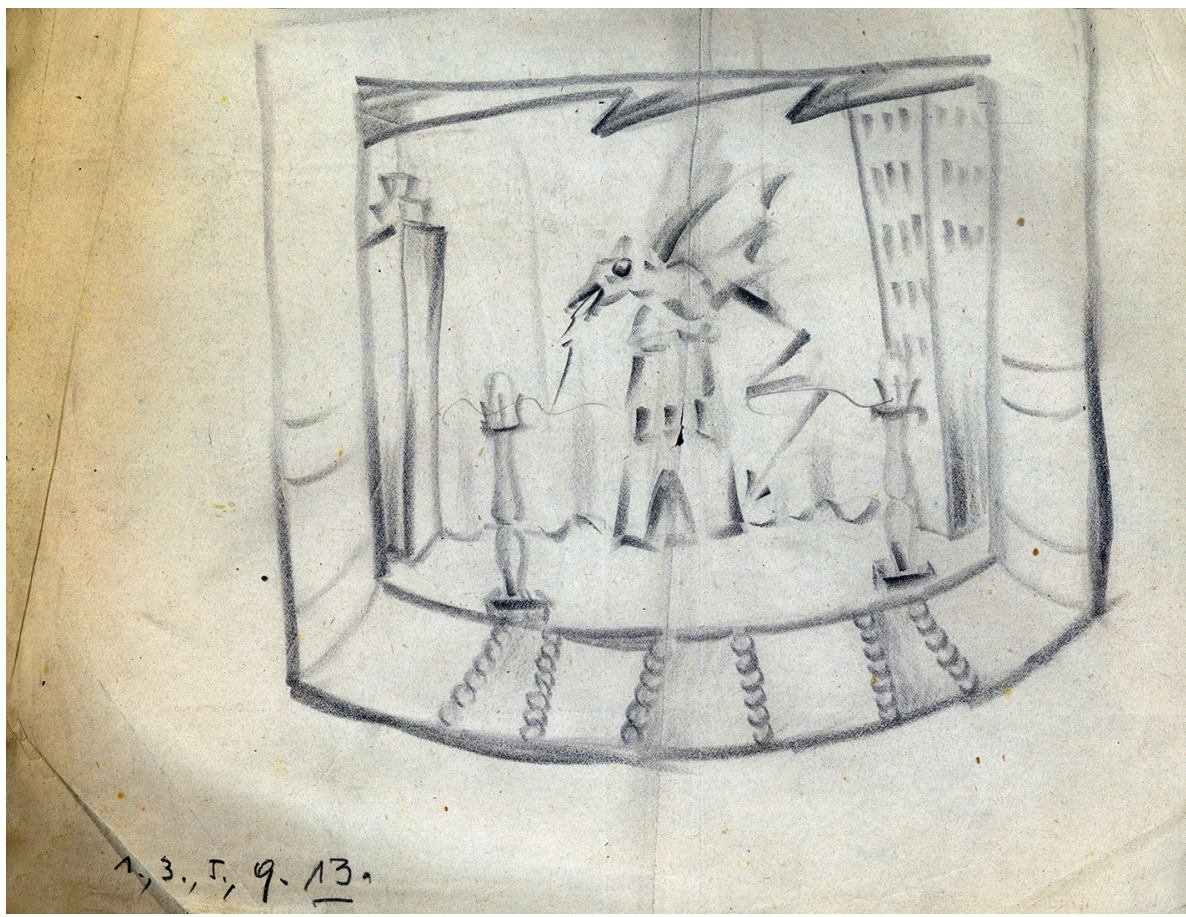

Slika I: Valo Bratina, Osnutek za prizore 3, 5, 9 in I3, risba s svinčnikom na papir, ni signirano, hrani Ikonoteka SLOGI - Gledališki muzej Ljubljana. M. Bravničar, Stoji, stoji Ljubljanica, premiera 2. I2. 1933, režija Bratko Kreft, scenografija Valo Bratina, Opera Narodnega gledališča v Ljubljani.

like, zgrajena $\mathrm{z}$ razkosanimi scenskimi elementi, med katerimi je bil tudi veliki, pokončni, vrteči se krog ter prej omenjena lestev, namenjena akrobacijam. Vsekakor je bila do tega trenutka to najsodobnejša scenografija na ljubljanskem opernem odru in po navdušenem aplavzu publike sodeč tudi daleč najuspešnejša.

Od scenografije za opereto Blejski zvon (24. 2. 1933), pri kateri je bil skladatelj Saša Šantel hkrati tudi scenograf, pa se je ohranil le skromen opis zunanjščine: »Blejski otok je v vsej svoji naravni lepoti tako rekoč pred nami.."4 Kakšna je bila njegova likovna podoba, je bil otok morda naslikan na prospekt ali na kuliso in ali je bil sestavljen iz scenskih elementov, pa ni znano.

Na sodoben način je Kreft uprizoril tudi večji del opernega opusa, tako Massenetovega Wertherja (4. 1. 1931), Bizetovo Carmen (20.12. 1931) in Ben-

24 č. [Emil Adamič], »Kulturni pregled. Premiera Šantlove operete«, Jutro 14, št. 50 (28. februar 1933): 4, http://www.dlib.si/?URN=URN:NBN:SI:doc-R89UMNVF. 


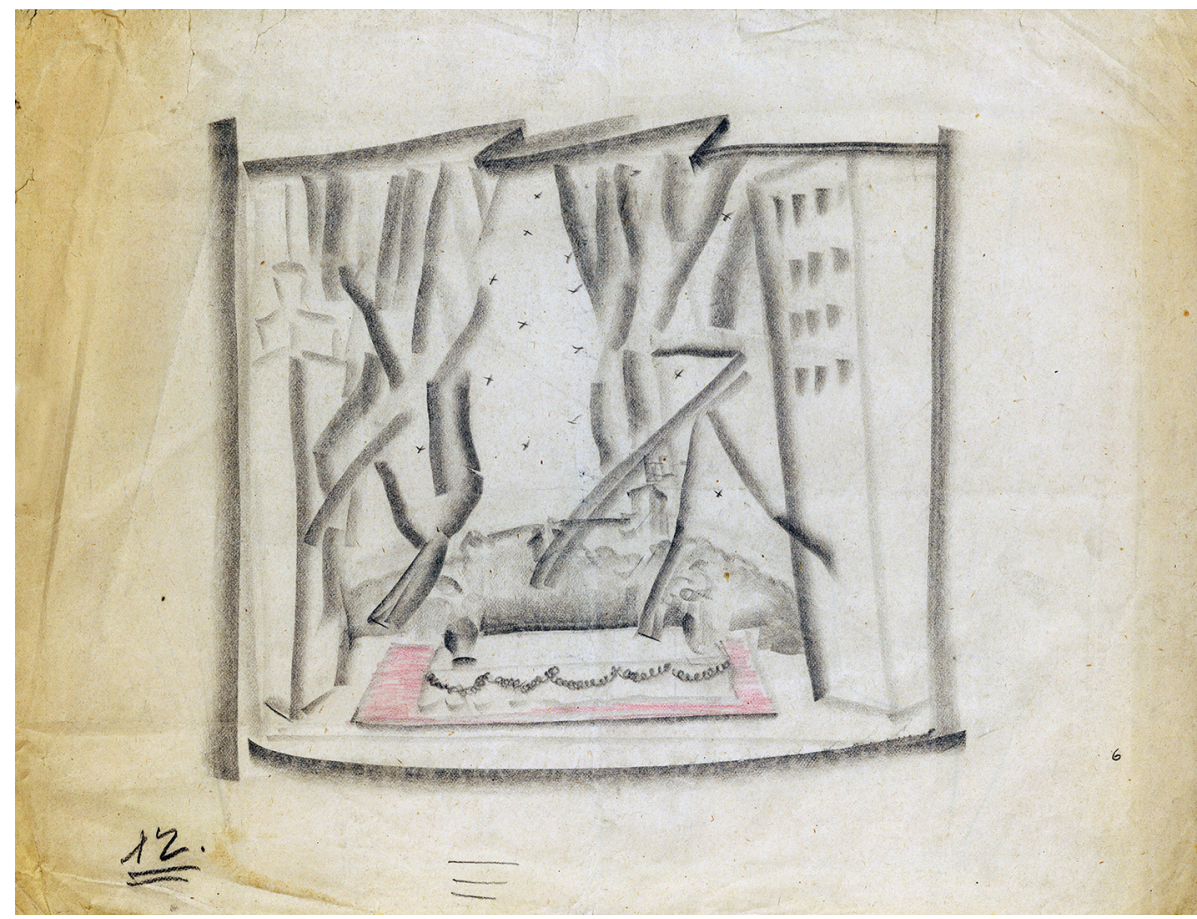

Slika 2: Valo Bratina, Osnutek za I2. prizor, risba s svinčnikom na papir, ni signirano, hrani Ikonoteka SLOGI - Gledališki muzej Ljubljana. M. Bravničar, Stoji, stoji Ljubljanica, premiera 2. 12. 1933, režija Bratko Kreft, scenografija Valo Bratina, Opera Narodnega gledališča v Ljubljani.

tazkyeve Tri mušketirje (18. 1. 1932), kjer sta s scenografom Uljaniščevim poleg svetlobne, uporabila tudi filmsko projekcijo, $\mathrm{z}$ duhovitimi in dovtipnimi podnaslovi. ${ }^{25}$

\section{Scenski osnutki za Bravničarjevo opereto}

Stoji, stoji Ljubljanica

Kot kaže so se v zbirki SLOGI - Gledališki muzej v zapuščini scenografa Vala Bratine (1887-1954) med nedefiniranimi scenskimi osnutki ohranile tudi podobe nekaterih prizorišč Bravničarjeve operete Stoji, stoji Ljubljanica (2. 12. 1933, režija Bratko Kreft, scenografija Valo Bratina, Opera Narodnega gledališča v Ljubljani). Gre za štiri skice, ki jih med seboj lahko pove-

25 Slavko Osterc, »Opera (Trije mušketirji - Gostovanja Druzovičeve, Mitovićeve in Šimenca)«, Domači prijatelj 6, št. 4 (1932): 120, http://www.dlib.si/?URN=URN:NB$\mathrm{N}: \mathrm{SI}: \mathrm{DOC}-\mathrm{Q} 6 \mathrm{JJ} 1 \mathrm{OST}$. 


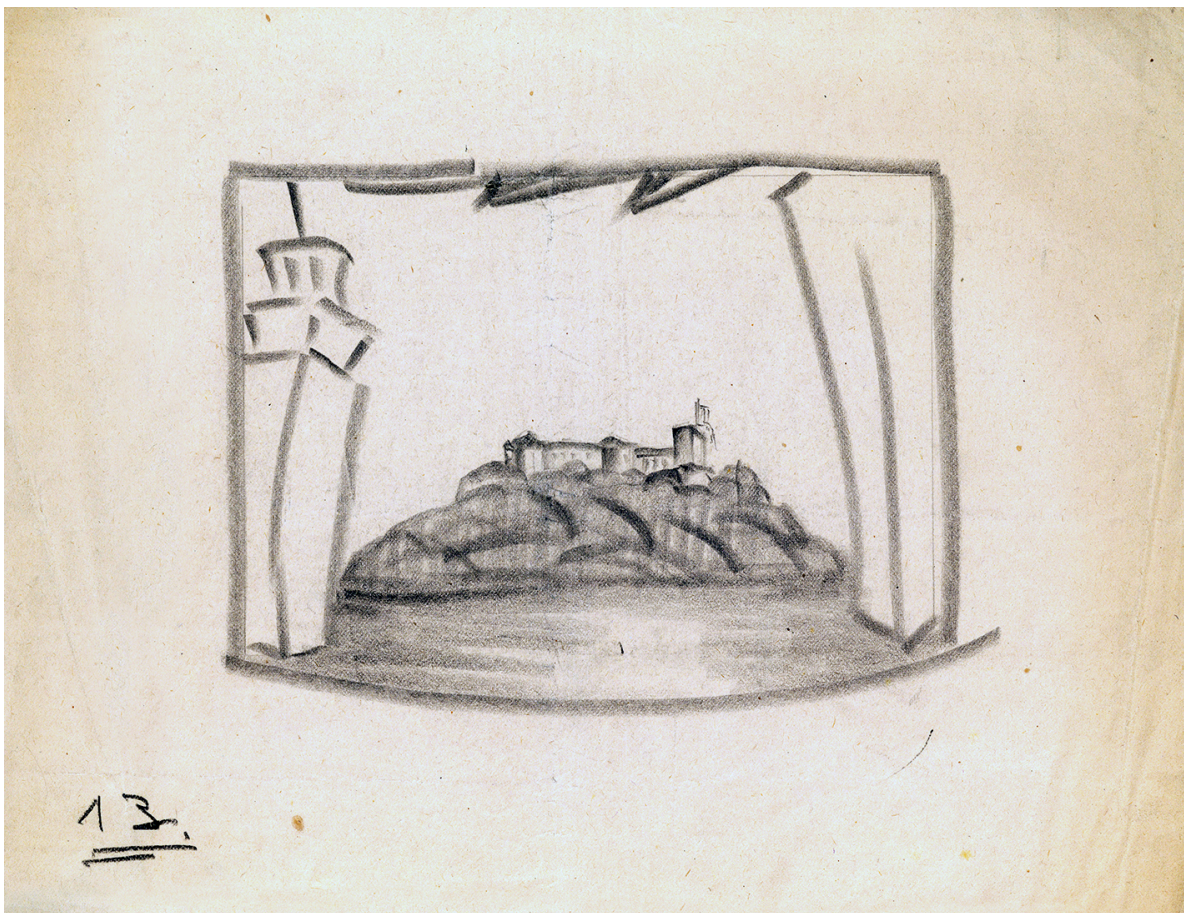

Slika 3: Valo Bratina, Osnutek za I3. prizor, risba s svinčnikom na papir, ni signirano, hrani Ikonoteka SLOGI - Gledališki muzej Ljubljana. M. Bravničar, Stoji, stoji Ljubljanica, premiera 2. 12. 1933, režija Bratko Kreft, scenografija Valo Bratina, Opera Narodnega gledališča v Ljubljani.

žemo zaradi enako naslikanega osnovnega motiva - okrašenega odrskega portala. Ob levi stranici je naslikana podoba ljubljanskega nebotičnika, na desni pa neznana visoka stolpnica. Prav ta okvir jih tudi loči od ostalega gradiva v Bratinovi mapi. Na njih so različni prizori Ljubljane, ki so edinstveni v Bratinovi zapuščini. Hkrati pa so na osnutkih zapisane številke prizorov, ki ustrezajo prizoriščem v libretu.

Osnutek za prizore 3, 5, 9 in 13 kaže zunanjščino, $\mathrm{z}$ dvema cestnima svetilkama (slika 1). Na sredi v ozadju odra pa stoji del ljubljanskega grba: grajski stolp z zmajem. Na osnutku za 12. prizor (slika 2) je v ozadju odra naslikan grajski hrib z gradom, ki je še bolj poudarjen na osnutku za 13. prizor (slika 3). Četrti, zadnji osnutek, ki ni oštevilčen, prikazuje notranjščino gostilne, nad mizo pa se pne neka žival, morda zmaj, morda lisica (slika 4). Morda bi ga lahko povezali s prizorom v restavraciji. Po ohranjenih podobah lahko zapišemo, da je Bratinova scenska zamisel temeljila na kulisah in 


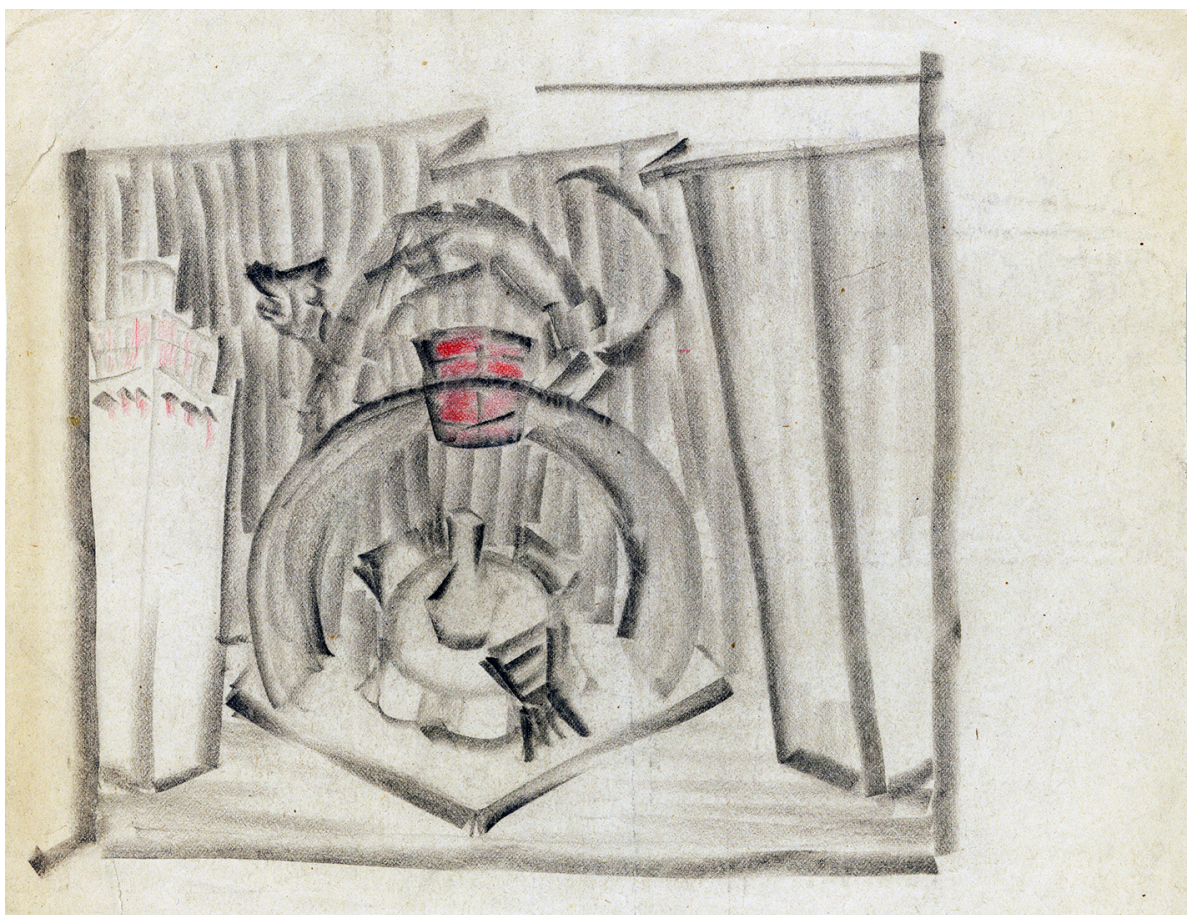

Slika 4: Valo Bratina, Osnutek za neznan prizor, risba s svinčnikom na papir, ni signirano, hrani Ikonoteka SLOGI - Gledališki muzej Ljubljana. M. Bravničar, Stoji, stoji Ljubljanica, premiera 2. I2. 1933, režija Bratko Kreft, scenografija Valo Bratina, Opera Narodnega gledališča v Ljubljani.

razgibanih zavesah, okrašenih in oblikovanih v stilu ekspresionizma, kar je bilo tudi sicer značilno za njegove scenske postavitve v tem obdobju.

Kot piše v gledališkem listu, je Bratina za opereto naredil 13 prizorišč. Poleg že omenjenih še podobo vinske kleti z različnimi pivskimi izveski, ki naj bi jih po odru razobesil kar režiser Kreft sam, in pa podobo s hotelskimi sobami. Očitno je šlo za več sob na istem prizorišču, saj imamo v kritiki ohranjen zapis, da naj bi vdirajoča, veseljaška množica razbila vrata leve hotelske sobe. ${ }^{26}$ Omenjen je bil še prizor z ljubljanskimi meglicami, ki so jih personificirale baletke. Te so plesale okrog Prešernovega spomenika. ${ }^{27}$ Sicer cember 1933): 2, http://www.dlib.si/?URN=URN:NBN:SI:doc-Z3SOBERB.

27 Ibid. 
je kritika pohvalila scenografijo ${ }^{28}$ s skromnimi besedami: »Predstava je bila po svoji živahnosti in opremi odra dobra in lepa. «"9

\section{Operetna scenografija ob režijah Ferda Delaka}

Avantgardni režiser Ferdo Delak je svoj prvi operni režijski debut opravil še kot gost $\mathrm{z}$ uprizoritvijo prirejene Offenbachove Robinzonade (12. 3. 1932, scenograf $V$. Uljaniščev). Pri snovanju predstave ni imel lahkega dela, saj so sočasno na opernem odru igrali tudi Kreftovo režijsko in scenografsko uspešnico La Mascotte. Uspešna postavitev je postala mlademu režiserju zgled. Predvsem se je naslonil na Kreftovo idejo celostne umetnine. V gledališkem listu je pojasnil, da je treba: »[Z]družiti igralsko, muzikalno, odrsko - scenično in koreografsko stran v eno celoto, ki naj ima na današnjem odru življenjsko upravičenost. "30 $^{30}$

Sodobno scenografijo sta si zamislila skupaj s scenografom Vasilijem Uljaniščevim. V napovedniku predstave $\mathrm{v}$ Jutru pa je bilo celo poudarjeno, da je scenske osnutke zanjo osnoval Ferdo Delak. ${ }^{31}$ Scenografija je bila minimalistična, grajena le s številnimi projekcijami in svetlobnimi učinki. Na platno sta projicirala sonce, na odrska tla pa migotanje sončnih lis. Delak je prednost scenografije s projekcijo pojasnil v gledališkem listu: »... dekoraci-

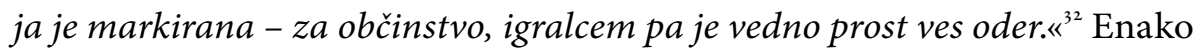
je menila tudi kritika: »Jako dekorativno (so) učinkovale vsaj tri slike Uljaniščeva, popolne zračnih dekoracij, ki so pripuščale igralcem nemoteno in neomejeno gibanje. ${ }^{33}$

28 Kritik Govekar jo je zaradi razvlečenosti in napak označil z besedami »Leži, leži Ljubljanca«. Nikolaj Pirnat, pisec libreta, slovenski slikar in karikaturist, pa je bil po premieri razočaran in je povedal, da v libretu, ki ga je močno predelal režiser Bratko Kreft, ne vidi več svojega avtorstva. Glej: Govekar, »Leži, leži Ljubljanca ...", 2.

Henrik Neubauer, Opereta v Sloveniji (Ljubljana: Glasbena matica, 2008), 85.

Ferdo Delak, »Robinzonada«, Gledališki list ljubljanske Opere 11, št. 10 (1931/32): 4, http://www.dlib.si/?URN=URN:NBN:SI:DOC-E1 $\mathrm{P}_{5} \mathrm{~F}_{5} \mathrm{~J}_{4}$.

Anon., »Gledališče. Ljubljanska opera«, Jutro 13, št. 61 (12. marec 1932): 7, http:// www.dlib.si/?URN=URN:NBN:SI:doc-914W3WWM.

Delak, »Robinzonada «, 4 .

č. [Emil Adamič], »Kulturni pregled. 'Robinzoniada' v ljubljanski operi«, Jutro 13, št. 63 (15. marec 1932): 3, http://www.dlib.si/?URN=URN:NBN:SI:doc-NBV8577P. Enega izmed kritikov pa so vseeno motili nekateri rekviziti, na primer konzerve z vilicami, s katerimi so se zapletali nastopajoči. Glej: Fr. G. [Fran Govekar], »Robinzonada", Slovenski narod 65, št. 60 (14. marec 1932): 2, http://www.dlib.si/?UR$\mathrm{N}=\mathrm{URN}: \mathrm{NBN}: \mathrm{SI}:$ doc-ZNZ4 $\mathrm{F}_{9} \mathrm{KO}$. 
Po tej prvi bolj ali manj uspeli uprizoritvi je Delak na oder ljubljanske opere postavil še slovensko operetno noviteto, Eriko (22. 10. 1932). Avtor operete Janko Gregorc (1905-1989) je pojasnil, da je izbral zvrst sodobne jazz-operete, ker je ta nova glasbena zvrst osvojila svet in prevzela tudi opereto. ${ }^{34}$ Novost je potrebovala sodobno režijo in scenografijo in to vse prej kot lahko nalogo sta prevzela režiser Delak in scenograf Uljaniščev. ${ }^{35}$ O scenski postavitvi ni veliko ohranjenega. Iz zapisov pa se zdi, da scenska podoba ni ustrezala vsebini oziroma je bilo prizorišče slabo zasnovano: "Samo tiste kabine (hiše?) na trgu so čudne. In da ljudje skačejo po strehah v današnjem Dubrovniku, nisem še videl. Pa da imajo dubrovniške hiše prozorne stene, je originalno. ${ }^{36}$

Med kritiki je le Slavko Osterc priznal nekaj kvalitete, predvsem zaradi naravne režije, živahnega gibanja in slikovitih slik, ${ }^{37}$ a je dodal, da se inscenator ni potrudil in da režiser Delak tudi ni mogel nič poštenega narediti iz pustega libreta. ${ }^{38}$

Preostale Delakove režije na ljubljanskem opernem odru so nastale le z nekaj skromnimi režijskimi in scenografskimi domislicami, zato se je med njegovimi ocenjevalci razširilo splošno mnenje, da se je »Delaku nekdanja revolucionarna gesta že ohladila ob dotiku z ledeno stvarnostjo. ${ }^{39}$

A tudi to ni čisto držalo. Leta 1935 se je Delak ponovno preskusil na mariborskem odru, kot režiser Kozinove operete Majda (24. 11. 1935). Te se je lotil z enako vnemo in idejami kot se je nekoč predstav na Delavskem odru v Ljubljani. Predelal oziroma priredil je libreto in $\mathrm{k}$ sodelovanju povabil svojega najljubšega scenografa, akademskega slikarja Ljuba Ravnikarja, $s$ katerim sta $v$ preteklosti zelo uspešno sodelovala prav pri modernizacijah in variacijah različnih dramskih in pesniških besedil. Tudi časopisi so zato pričakovali nekaj posebnega in napovedovali opereto, ki bo »zrežirana in inscenirana na revijski način «. ${ }^{40}$ Delak in Ravnikar sta v potek uprizoritve ustavila različne scenografske vložke. Pred vsako pesmijo so na pri-

Janko Gregorc, »Erika«, Gledališki list ljubljanske Opere 12, št. 3 (1932/33): 2, http:// www.dlib.si/?URN=URN:NBN:SI:DOC-TTEDHBYL.

č. [Emil Adamič], »Kulturni pregled. Premijera 'Erike' v operi«, Jutro 13, št. 249 (25. oktober 1932): 3, http://www.dlib.si/?URN=URN:NBN:SI:doc-oILLEYTM.

36 Neubauer, Opereta $v$ Sloveniji, 73.

37 Slavko Osterc, »Gledališki pregled. Opera. Janko Gregorc: 'Erika' - Sergej Prokofjev: 'Zaljubljen v tri oranže'«, Domači prijatelj 7, št. 1 (1933): 12, http://www.dlib.si/?UR$\mathrm{N}=\mathrm{URN}: \mathrm{NBN}$ :SI:DOC-U8G8JMNQ.

38 Ibid.

39 Moravec, Slovenski režiserski kvartet (z gostom), 91.

40 Neubauer, Opereta $v$ Sloveniji, 56. 
mer spustili poseben zastor s karikiranimi zapisi vsebine, med prizori pa tudi zastor s simboličnimi slikami, s katerimi sta uspešno povečala zunanji efekt in notranjo poglobljenost. ${ }^{41} \mathrm{Na}$ eni izmed ohranjenih fotografij (na njih se vidi le nekaj scenskih elementov) se je ohranila podoba nastopajočih na motorju. Scenska postavitev je bila $\mathrm{v}$ kritikah deležna posebne pohvale: »... Ravnikar je postavil sceno $z$ izjemnim poznavanjem premagovanja ploskovitih, prostorskih in časovnih težav. ${ }^{42}$ Uprizoritev je postala tudi sezonska uspešnica. ${ }^{43} \mathrm{~Pa}$ vendar je eden izmed kritikov Delaka proglasil za »šmirantskega direktorja «, ki pripravlja opereto $\mathrm{z}$ »vaškimi diletanti«. ${ }^{44}$

\section{Scenograf Bojan Stupica in mariborski operetni oder}

$\mathrm{V}$ tridesetih letih dvajsetega stoletja je začel svoje prve režijske in scenografske korake tudi mladi Bojan Stupica. Ker v Ljubljani zanj ni bilo dela, je odšel v Maribor. Še kot študent je sodeloval v mariborskem dramskem gledališču in uprizoril Begovićevo dramo Brez tretjega (23. 4. 1932). Igro je uspešno režiral in ji osnoval scenografijo s predmeti iz vsakdanjega življenja, kar je bila izredno drzna in sodobna poteza. $Z$ odra je odstranil vse zastarele kulise in prospekte ter uporabil realne predmete. Odrski prostor je gradil z brvmi, mostovži, bauhausovsko navdihnjenim pohištvom ter žičnatimi, mrežastimi pregradami in celo s pravimi rastlinami (grmičevje, drevesa). Vse to pa popestril še z igro svetlobnih efektov. S scensko postavitvijo se je premaknil v smer nove stvarnosti, ki je bila tedaj priznana kot sodobna smer tudi v slovenski likovni umetnosti. Brez tretjega je postala uspešnica in $\mathrm{z}$ njo je gostoval $\mathrm{v}$ Zagrebu. ${ }^{45}$

Po tem uspehu pa ga je režiser Vladimir Skrbinšek (1902-1987) povabil kot sorežiserja in scenografa k postavitvi Stolzovega Izgubljenega valčka (25. 12. 1934). Slikovno gradivo predstave ni ohranjeno. Se je pa v dnevnem časopisju ohranil pomemben zapis o Stupičevih sodobnih avantgardnih poskusih v scenografiji. V zadnjem prizoru je namreč dogajanje $\mathrm{z}$ odra preselil $\mathrm{v}$ parter med gledalce. ${ }^{46}$ Ena glavnih teženj slovenskih avantgardnih gledaliških snovalcev od prvih poskusov Avgusta Černigoja na odru pri sv. Jako-

41 Kocjančič, Prostor $v$ prostoru, vol. I., 241.

42 Neubauer, Opereta $v$ Sloveniji, 57.

43 Ibid.

44 Ibid., 56.

45 Kocjančič, Prostor $v$ prostoru, vol. I., 154.

46 c., »Mariborsko gledališko pismo«, Jutro 15, št. 298 (29. december 1934): 4, http:// www.dlib.si/?URN=URN:NBN:SI:doc-D3 CC6KO6. 
bu v Trstu je namreč bila prav tesnejša povezava publike $\mathrm{z}$ igralci prek odrske rampe, oziroma t. i. rušitev četrte stene odra. Stupica je očitno to idejo prvi prenesel na poklicne odre prav pri tej uprizoritvi. Tako so bili gledalci še bolj povezani s predstavo in nastopajočimi. ${ }^{47}$

\section{Suppejev "Boccaccio« in konstrukcija vrtljivega odra Ernesta Franza (1906-1981)}

Slovenski scenografi so morali svoje sodobne scenske zamisli v času med vojnama ves čas prilagajati slabemu tehničnemu stanju odrov. Ob različnih odrskih prenovah so izboljševali tudi tehnično stanje odrov. Tako je ob zadnji prenovi odra v sezoni 1934/35 ljubljanska opera dobila nastavljiv vrtljiv oder. Nastavljiv »Krožni oder « ali »krožno ploščo«, kot so to tehnično novost tedaj imenovali, so naredili po načrtih inženirja Josipa Černivca (slika 5). Naložba je bila draga, zato so nakup opravičili z besedami: »Teorija in praksa novodobne gledališke inscenacije zahtevata ustvaritev možnosti za hitro menjavanje slik na odru. ${ }^{48}$ Odločili pa so se za cenejšo varianto nastavljivega oziroma premičnega, montažnega, vrtljivega odra, ki se ga je sestavilo le po potrebi. Imel je $10 \mathrm{~m}$ premera, $25 \mathrm{~cm}$ konstrukcijske višine in je tekel v središčnem krogličnem ležišču na 16 nosilnih tramovih. Tramovi so bili na koncu opremljeni s kolesi, ki so tekla po železni tračnici podloženi s klobučevino. Ploščo je izdelala ljubljanska tvrdka Škafar. ${ }^{49}$

Od tega trenutka dalje so scenografije na opernem odru postale dinamične. Scenske postavitve so se velikokrat vrtele, prizori pa so si sledili hitro, brez hrupnih in motečih prekinitev predstav.

Tehniško novost so prvič uporabili prav pri opereti. Veselje ob krstu naprave je pripadlo novemu hišnemu scenografu, arhitektu Ernestu Franzu. Pri uprizoritvi Suppéjevega Boccaccia (28. 4. 1935, režija Niko Štritof) ga je uporabil v funkciji preprostega vrtiljaka. A kot se rado zgodi, se je nova tehniška igračka pokvarila, zato so morali pri ponovitvah scenografsko zamisel opustiti.

Popravljen vrtljivi oder so kot pravo odrsko »čarovnijo « spet uporabili pri Hervéjevi Mam'zell Nitouche (26. 10. 1935), kjer sta režiser Bratko Kreft in scenograf Ernest Franz popolnoma izkoristila njegovo vrtljivost. Kot piše kritik v Jutru je bila krožna plošča razdeljena na tri različne segmente - pri-

47 Ibid.

48 Anon., »Krožni oder«, Gledališki list ljubljanske Opere 14, št. 12 (1934/35): 92, http:// www.dlib.si/?URN=URN:NBN:SI:DOC-GO6M6LAM. 


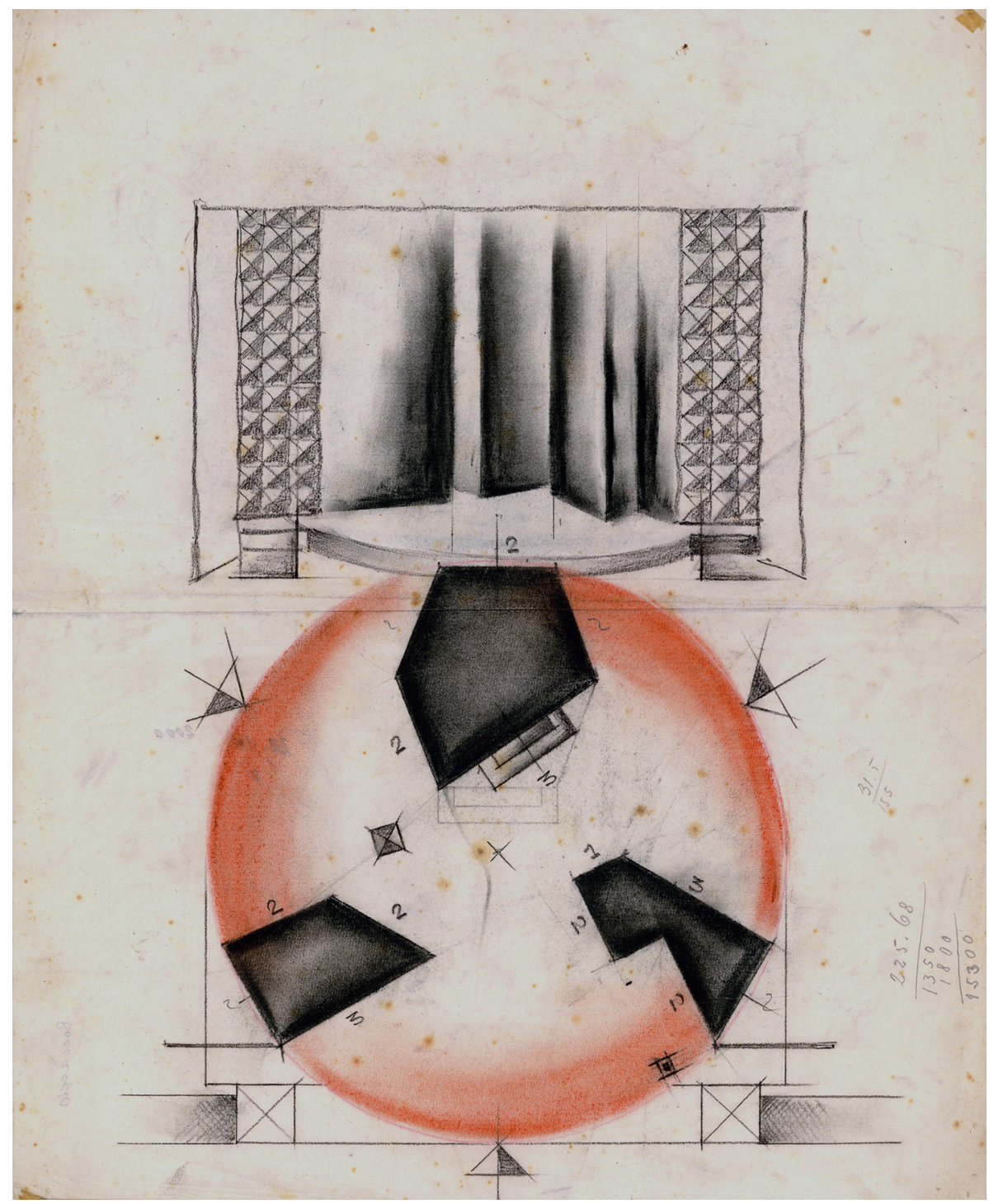

Slika 5: Tlorisna skica vrtlivega odra, po načrtih inženirja Josipa Černivca, sezona 1934/35, hrani Ikonoteka SLOGI - Gledališki muzej Ljubljana. 
zorišča. V njih je bila le najnujnejša scenska oprema: nekaj predmetov s podobo otroških igral, hišic in figuric, dva lesena konja in kočija. In vse te lesene igračke so se vrtele skupaj s ploščo, tako kot tudi prizorišča in igralci na njih..$^{50}$ Vrteča se minimalistična scenografija je postala prava senzacija, tudi zato, ker je prikazala tudi hitro in tiho menjavo prizorišč. Očarani kritik je zapisal: »To je lutkovni teater, nekaka Pandorina škatla, iz katere se sipljejo čudežne igračice«."

\section{Avantgardni poskusi v scenografiji operet kot gibalo in povod za scenografski razvoj}

Scenografske in režijske novosti so torej na oder operne hiše na pobudo ravnatelja Mirka Poliča prinesli dramski režiserji Bratko Kreft, Ferdo Delak in Bojan Stupica ob sodelovanju scenografov Vasilija Uljaniščeva in Ljuba Ravnikarja. Kot kaže so sprva poskusili uveljaviti sodobne scenografske prijeme prav pri operetah $\mathrm{z}$ vpeljavo filmske projekcije in projiciranja svetlobnih vzorcev, $\mathrm{z}$ različnimi svetlobnimi efekti, s postavitvijo realističnih scenskih elementov, $\mathrm{z}$ uporabo navadnih predmetov iz okolja, tudi rastlin ter $\mathrm{z}$ idejo rušenja meje med igralci in publiko prav s pomočjo scenskih elementov postavljenih $\mathrm{v}$ parterju. Za večjo razgibanost odrskega prostora in dinamiko predstav so uporabljali nove tehnične naprave, praktikable in nastavljiv vrtljiv oder. Pri operetah so lahko preskusili nekaj drznih scenskih in režijskih novosti oziroma tudi načine, ki so bili komaj sprejemljivi za konservativno publiko in kritiko. Lahko bi rekli, da je mlajši generaciji režiserjev prav opereta pomenila odskočno desko, pa čeprav se je velikokrat zgodilo, da so sodobne prijeme zaradi slabih kritik in razočaranega občinstva hitro opustili. Njihovo drznost so včasih opravičevali celo kritiki. Tako je na primer Slavko Osterc zagovarjal operno in operetno delo Bratka Krefta predvsem z gledišča dobrega finančnega priliva:

Čeprav se ne strinjamo vsi $z$ njegovimi novotarijami (jaz se strinjam), ne smemo nikdar pozabiti, kako uspešno je debitiral z 'Maskoto' in koliko predstav je napolnil s 'Carmen' in sedaj z 'Mušketirji'. To se pri gledališki blagajni pozna - zlasti v sedanjih težkih časih, ko zavzemajo krize in lamentacije vedno večji obseg. ${ }^{52}$

50 M. R., «Kulturni pregled. Nova 'Nitouche' v operi«, Jutro 16, št. 248 (25. oktober 1935): 7, http://www.dlib.si/?URN=URN:NBN:SI:doc-IWNL62PW.

51 č. [Emil Adamič], »Kulturni pregled. Nova 'Mamzelle Nitouche'«, Jutro 16, št. 252 (30. oktober 1935): 7, http://www.dlib.si/?URN=URN:NBN:SI:doc-8C5JEWoD. 
Po letu 1930 se je torej odrska podoba predstav začela spreminjati in prav scenografske in režijske novosti, preskušene v operetnem miljeju, so kmalu prešle na operne in gledališke predstave in se usidrale v podobo naših poklicnih gledališč.

\section{Bibliografija}

Anon. »Gledališče. Ljubljanska opera«. Jutro 13, št. 61 (12. marec 1932): 7. http:// www.dlib.si/?URN=URN:NBN:SI:doc-914W3WWM.

Anon. »Krožni oder«. Gledališki list ljubljanske Opere 14, št. 12 (1934/35): 92-4. http://www.dlib.si/?URN=URN:NBN:SI:DOC-GO6M6LAM.

Anon. »Stremljenje obraznikov v gledališču (razgovor urednika z Milanom Skrbinškom)«. Jutro: ponedeljska izdaja 12, št. 294a (21. december 1931): 2. http://www.dlib.si/?URN=URN:NBN:SI:DOC-HXOQISCF.

c. »Mariborsko gledališko pismo«. Jutro 15, št. 298 (29. december 1934): 4. http:// www.dlib.si/?URN=URN:NBN:SI:doc-D3CC6KO6.

č. [Emil Adamič]. »Kulturni pregled. 'Robinzoniada' v ljubljanski operi«. Jutro 13, št. 63 (15. marec 1932): 3. http://www.dlib.si/?URN=URN:NBN:SI:docNBV8577P.

č. [Emil Adamič]. »Kulturni pregled. Premijera 'Erike' v operi«. Jutro 13, št. 249 (25. oktober 1932): 3-4. http://www.dlib.si/?URN=URN:NBN:SI:docoILLEYTM.

č. [Emil Adamič]. »Kulturni pregled. Premiera Šantlove operete«. Jutro 14, št. 50 (28. februar 1933): 4. http://www.dlib.si/?URN=URN:NBN:SI:doc -R89UMNVF.

č. [Emil Adamič]. »Kulturni pregled. Nova 'Mamzelle Nitouche'«. Jutro 16, št. 252 (30. oktober 1935): 7. http://www.dlib.si/?URN=URN:NBN:SI:doc$8 \mathrm{C}_{5}$ JEWoD.

Delak, Ferdo in August Černigoj. »Kaj je umetnost? Moderni oder«. V TANK! Slovenska zgodovinska avantgarda, ur. Breda Ilich Klančnik in Igor Zabel, 50-1. Ljubljana: Moderna galerija, 1998.

Delak, Ferdo. »Scenični osnutki Kogojeve opere Črne maske«. Ilustracija 1, št. 6 (1929): 182.

Delak, Ferdo. »Robinzonada«. Gledališki list ljubljanske Opere 11, št. 10 (1931/32): 3-4. http://www.dlib.si/?URN=URN:NBN:SI:DOC-E1 $\mathrm{P}_{5} \mathrm{~F}_{5} \mathrm{~J}_{4}$.

Fr. G. [Fran Govekar]. »Robinzonada«. Slovenski narod 65, št. 60 (14. marec 1932): 2. http://www.dlib.si/?URN=URN:NBN:SI:doc-ZNZ4FFKO. 
Fr. G. [Fran Govekar]. »Leži, leži Ljubljanica ...«. Slovenski narod 66, št. 276 (4. december 1933): 2. http://www.dlib.si/?URN=URN:NBN:SI:doc-Z3SOBERB.

Gregorc, Janko. »Erika«. Gledališki list ljubljanske Opere 12, št. 3 (1932/33): 1-2. http://www.dlib.si/?URN=URN:NBN:SI:DOC-TTEDHBYL.

I. V. »Delavski oder 'Svobode' v Ljubljani. Uprizoritev Cankarjevega 'Hlapca Jerneja in njegove pravice' v operi. - Nova inscenacija. - Govorilni zbor«. Delavska politika 7, št. 41 (21. maj 1932): 3.

K. B. [Bratko Kreft]. »Nekaj o inscenacijskih problemih (Odlomek iz študije 'Problemi sodobnega gledališča')«. Gledališki list ljubljanske Drame 18, št. 7 (1938/39): 53-6. http://www.dlib. si/?URN=URN:NBN:SI:DOC-CCGKOBED.

Kalan, Filip. "Evropeizacija slovenske gledališke kulture«. V Linhartovo izročilo, ur. Lojze Filipič, 30-168. Ljubljana: Drama Slovenskega narodnega gledališča, 1957.

Kocjančič, Ana. Prostor v prostoru, Scenografija na Slovenskem od 17. stoletja do leta 1991. Vol. I in Vol. II. Ljubljana: Slovenski gledališki inštitut, 2018.

M. R. »Kulturni pregled. Nova 'Nitouche' v operi«. Jutro 16, št. 248 (25. oktober 1935): 7. http://www.dlib.si/?URN=URN:NBN:SI:doc-IWNL62PW.

Moravec, Dušan. Slovenski režiserski kvartet (z gostom). Ljubljana: Slovenski gledališki in filmski muzej, 1996.

n. »Narodno gledališče. 'Mam'zelle Nitouche'«. Slovenski narod 52, št. 23 (28. januar 1919): 3. http://www.dlib.si/?URN=URN:NBN:SI:doc-R2BQ3BGH.

Neubauer, Henrik. Opereta v Sloveniji. Ljubljana: Glasbena matica, 2008.

Osterc, Slavko. »Opera (Trije mušketirji - Gostovanja Druzovičeve, Mitovićeve in Šimenca)«. Domači prijatelj 6, št. 4 (1932): 120-1. http://www.dlib. si/?URN=URN:NBN:SI:DOC-Q6JJ1OST.

Osterc, Slavko. »Gledališki pregled. Opera. Janko Gregorc: 'Erika' - Sergej Prokofjev: 'Zaljubljen v tri oranže'«. Domači prijatelj 7, št. 1 (1933): 12. http:// www.dlib.si/?URN=URN:NBN:SI:DOC-U8G8JMNQ.

Tank: revue internationale active. Ljubljana: Josip Pavliček, 1927. 